\title{
Melody As An Educational Instrument To Create A Better Environment In Elt Classroom
}

\section{Dr A. Kavitha*}

\begin{abstract}
Young children are learning a second language benefit extensively from songs. The usage of songs in English Language Teaching schools throughout the world is a witness to this. The concept of this study is to scrutinize why pieces may be helpful to teaching aids. It will examine how songs may be used to teach vocabulary and sentence structures and how they can assist learners in improving their listening skills and pronunciation. Integrating English songs into ELT is one pedagogical option. Song, which combines music and lyrics, has many inherent qualities, including a kaleidoscope of culture, expressiveness, reliability, and therapeutic effects, all of which make it an excellent resource for language instruction. This study presents both theoretical and practical justifications for utilizing English songs in ELT.
\end{abstract}

Keywords: Songs, Teaching English Language, pedagogical, listening skills, pronunciation and ELT.

*Assistant Professor, Ethiraj College for Women, Egmore, Chennai-8. 
Listening is the first modality of language acquisition for children. It serves as the basis for all elements of linguistic and cognitive development and plays a lifelong role in communication processes. One of the strategies that the lecture might employ is the use of music to teach listening. The use of music will pique the students' interest in participating in the listening class. When the listening class constantly offers the same type of audio, the students become bored. In this study, the lecture employed songs since it was an engaging resource used by English lectures.

Most youngsters love singing songs, and it may provide a welcome respite from the monotony of learning a new language. For the educator, using music in the classroom might give a pleasant break from a rigorous curriculum. Songs may be taught to any number of students, and even teachers with little resources can utilize them effectively. Songs can aid the acquisition of linguistic skills in young children learning a second language. On the other hand, Songs may be used ineffectively, and the potential for language development may be neglected. The goal of this research is to symbol out why songs are such helpful teaching aids.

Songs have been delightful companions for humans for as long as we can remember, perhaps not longer. It might be beneficial to foreign language education as a crucial part of our language learning experience. Because of their various benefits, songs may also enrich and enliven our foreign language education. Music is essential in generating a comfortable and enjoyable environment in which language learning may take place, according to Suggestopedia.

The flexibility of songs is one of the advantages of using them in the classroom with young students. Songs may be used for several purposes, and they can be considered a good teaching tool for a variety of reasons. Pieces can help young pupils strengthen their listening and pronunciation skills, allowing them to speak more clearly. Songs may help students acquire vocabulary, phrase structures, and sentence patterns while expressing their mother language culture. The fact that pieces may be fun is perhaps the essential benefit of using them in the classroom.

According to Purcell, children might grow bored while comprehending the meaning of new words or phrases in context by repeatedly listening to a narrative or conversation. Listening to a song, again and again, might feel less tedious due to the rhythm and melody. 
Some songs, such as Hello, contain common expressions and can be used as suitable listening activities.

Songs can also help youngsters build hearing skills by listening to various kinds of intonation and rhythm. English has a stressful rhythm that might enable pieces to make you feel. Music can be printed on our brains, Murphey thinks, that "songs are based on our shortterm and long-term memory" and hence suitable tools for use in language schools.

Songs may be used in a variety of ways in the classroom. The process is influenced by the pupils' academic level, hobbies and ages, the grammatical point to be covered, and the song itself. Apart from that, it is primarily dependent on the teacher's inventiveness. According to Brown (2006), the procedure for any listening activity can be done by activating prior knowledge, helping students organize their learning by thinking about their listening purposes, and using well-structured speaking tasks informed by research if speaking is also a goal of the classroom.

Songs have a lot of emotion. Some tell an exciting and engaging story; others reflect ambitions and objectives, while others recall a bygone era. Themes and words that resonate with the learner abound throughout songs. Language development is aided by music and singing. Music and language are so intertwined in the lives of newborns that Language development is aided by music and singing. Music and language are so intertwined in the lives of newborns that awareness of music is critical to a baby's language development and even helps to cement the bond between infant and mother.

Music may be very beneficial to those learning a new language. As you probably know from your language studies, listening to songs and singing is a natural and enjoyable way to acquire new sounds, words, and phrases. Learning a piece of music or a musical instrument is analogous to learning a language in many ways. We'll be required to build and use a sound library, learn new patterns and concepts, and master song and composition "syntax." As musicians gain proficiency, they, like language learners, get closer and closer to the goal sounds until they achieve a level of comfort and delight, or "fluency." As musicians gain proficiency, they, like language learners, get closer and closer to the goal sounds until they achieve a level of comfort and delight, or "fluency."

Pop songs, for example, are a great way to teach English to non-native speakers (ELLs). In his well-known work, Tim Murphey investigated why pop songs appear to be 
particularly effective in teaching English to ELLs. He observed that pop songs have a unique mix of high-frequency words that are repeated repeatedly and the use of the first and second person. As a result, listeners connect with the songs on an emotional and intimate level. They, like language learners, create ever-closer approximations as their competence grows.

The requirement for pupils to be able to communicate in English is increasing. Listening comprehension, in particular, has recently received a lot of attention among university students. Despite having learned the fundamentals of English, such as grammar and vocabulary, students' listening comprehension is generally poor. One of the four abilities that children develop in the classroom is the ability to listen. Listening is also the most needed part of the receptive skill in English learning, according to Feyten. Listening has emerged as a crucial component in second language acquisition, as stated by Feyten (1991). Listening is a great way to learn.

Songs employ basic conversational vocabulary and a lot of repetition in general. They can significantly stimulate the language acquisition process of repetition, which many teachers search for in sample texts. The pupils will be activated to acquire many pattern exercises without even recognizing it because of the repetition given in songs. I also concluded that pieces provide a lot of practice for students to organically link the sounds of phrases or words as they listen and sing along with the recording, allowing them to enhance their pronunciation and usage of natural English reductions without even realizing it. Songs make it easier to learn a language in a fun and effective way.

Songs make it easier to learn a language in a fun and efficient way. This type of culture is available to the majority of our pupils. Songs that deal with societal concerns or cultural themes are good options. Students may engage in, exploit, and feel the significance of the songs by using a learner-centred method. Students will produce a lot of language as a result of the interactive and reflective learning process. The proper content selection and structured and logical lesson planning can help enhance listening comprehension through songs.

Learning goals and the relevance and adaptability of the chosen texts must be considered while selecting good songs. To perform systematic lesson planning, we should have clearly defined goals for each lesson plan; carefully construct listening activities ranging from the simplest to the most complicated; ask for active, overt student engagement; and 
listen with teaching rather than testing purpose. Furthermore, developing gist listening, selective listening, and hearing for information are all essential skills.

\section{Conclusion}

English Language Teaching (ELT) classrooms use songs to teach vocabulary and sentence structures. Pieces can aid the acquisition of linguistic skills in young children learning a second language. They can also assist learners in improving their listening skills and pronunciation and helping strengthen their listening and pronunciation skills.

\section{Work Cited}

Brewster, Jean, et al. The Primary English Teachers Guide. Penguin English, 2015.

Deutsch, Diana. "Speaking in Tones." Scientific American Mind, vol. 21, no. 3, 2010, pp. $36-$

43., doi:10.1038/scientificamericanmind0710-36.

Feyten, Carine M. “The Power of Listening Ability: An Overlooked Dimension in Language

Acquisition." The Modern Language Journal, vol. 75, no. 2, 1991, pp. 173-180. JSTOR, www.jstor.org/stable/328825. Accessed 2 Sept. 2021.

Larsen-Freeman, Diana. Techniques and Principles in Language Teaching. Oxford University Press, 2000.

Murphey, Tim. Music \& Song. Oxford University Press, 1992.

Purcell, John M. "Using Songs to Enrich the Secondary Class." Hispania, vol. 75, no. 1, 1992 ,

pp. 192-196. JSTOR, www.jstor.org/stable/344779. Accessed 2 Sept. 2021.

"Rhymes, Stories and Songs in the ESL Classroom." Brown - Rhymes, Stories and Songs in the ESL Classroom (TESL/TEFL), iteslj.org/Articles/Brown-Rhymes.html.

"Songs of Experience: The New York Academy of Sciences." Nyas, www.nyas.org/ebriefings/songs-of-experience/. 